\title{
Tobacco industry access to policy elites and the implementation of Article 5.3 of the WHO Framework Convention on Tobacco Control
}

\author{
Marc C Willemsen $\odot{ }^{1,2}$ Gary Fooks $^{3}$
}

\begin{abstract}
${ }^{1}$ Health Promotion, Maastricht University CAPHRI School for Public Health and Primary Care, Maastricht, The Netherlands ${ }^{2}$ Tobacco Control, Trimbosinstituut, Utrecht, The Netherlands

${ }^{3}$ School for Languages and Social Science, Aston University, Birmingham, UK
\end{abstract}

\section{Correspondence to}

Professor Marc C Willemsen, Health Promotion, Maastricht University CAPHRI School for Public Health and Primary Care, Maastricht 6200MD Netherlands;

marc.willemsen@

maastrichtuniversity.nl

Received 28 June 2019 Revised 29 October 2019 Accepted 1 November 2019 Published Online First 17 December 2019
ABSTRACT

Introduction Article 5.3 WHO Framework Convention on Tobacco Control (FCTC) aims to prevent tobacco industry interference with public health policy. The degree of protection depends on several factors: the interpretation of Article 5.3 by governments; the presence of codes of practice; and the effectiveness of industry lobbying versus public health advocacy. We examine these factors with reference to the Dutch government's interpretation of Article 5.3.

Methods We searched the Dutch Tobacco Industry Special Collection, part of the Truth Tobacco Industry Documents archive, containing more than 1100 Dutch government documents.

Results Between 2007 and 2012, under consistent pressure from the industry, an initial strict view of Article 5.3 gave way to increased contact with the industry. The industry tried to shift the governance of tobacco policy back to the Ministry of Economic Affairs. Around 2010, Dutch public health advocates began to use Article 5.3. Efforts included naming and shaming government contact with the industry, parliamentary questions about industry-government contact, a report outlining how Article 5.3 should be observed and, most importantly, a court case. In response to this, the government produced a formal code of practice, which was used to prevent industry involvement in the development of a new National Prevention Accord.

Discussion The Dutch government's initial decision not to codify Article 5.3 created an administrative environment in which health ministers' interpretation of Article 5.3 was able to shift according to their political beliefs. The findings support the recommendation that Parties to the FCTC take a strict approach and formally codify Article 5.3 to ensure effective implementation.

\section{INTRODUCTION}

Article 5.3 of the WHO Framework Convention on Tobacco Control (FCTC) calls on Parties to protect tobacco policy from 'commercial and other vested interests of the tobacco industry'. ${ }^{1}$ In 2008, the Conference of the Parties (COP) to the FCTC adopted guidelines for the implementation of the Article (hereafter the Guidelines). ${ }^{2}$ These focus on reducing the industry's status as political 'insiders' ${ }^{3}$ and, among other things, advocate that governments limit interactions with tobacco industry actors, conduct interactions transparently and refrain from accepting industry assistance in developing tobacco control policy.

In practice, the degree of protection provided by Article 5.3 will depend on how the Article is acted on by governments. ${ }^{45}$ Article 5.3 is broadly defined and does not specify the steps governments should take to protect health policy from industry interference. Research into how Article 5.3 has been operationalised suggests that implementation of the Guidelines is highly selective, ${ }^{6}$ which creates administrative space for continuing opportunities for tobacco industry interference. ${ }^{57}$ This study seeks to build on these previous analyses of Article 5.3 compliance. Specifically, the study aims to: (A) examine how the Dutch government has interpreted Article 5.3 in response to industry lobbying and public health advocacy; (B) build on the existing literature by examining in depth the thinking behind and political context to governments' interpretation of Article 5.3.

The Dutch context offers an important case study for several reasons. First, because of its strong corporatist tradition, where the governance of social and economic policy is characterised by incorporating all organised interests, including the business community, in the formation and implementation of policy. ${ }^{89}$ The Netherlands thus provides a basis for exploring how policy actors reconcile international obligations that seek to exclude economic actors from policy development with institutional norms otherwise favouring inclusion. Historically, Dutch corporatism in the domain of tobacco control policy has been exemplified by biannual in-person meetings between the Minister of Economic Affairs, the Minister of Health, senior civil servants and senior representatives of the tobacco industry (formally described as 'ministerial meetings') until $1996 .^{10}$

Second, like many other countries, the Netherlands initially eschewed codification of Article 5.3 and its Guidelines: its early Party reports to the COP noted that 'no official legislation or actions are taken to implement the guideline on art. 5.3, nevertheless we try to act within the spirit of the guidelines.' ${ }^{11}$ Previous research has highlighted the risks inherent in non-codified general commitments which arise when there is a change of government. ${ }^{5}$ Examining industry political activity and responses by the government in the Netherlands illustrates how industry actors seek to navigate shifting political landscapes where government-industry relationships are not governed by formal codes of practice.

Third, the Netherlands was one of the five 'key facilitating countries', next to Brazil, Ecuador, Palau and Thailand, which volunteered to be members of the Working Group on Article 5.3, responsible for drafting of the Guidelines for the third session 
of the FCTC Conference of the Parties (COP3) in Durban in 2008. ${ }^{12}$ The Netherlands also provided the chair of the Working Group.

\section{METHODS}

Our analysis is primarily based on government documents in the Truth Tobacco Industry Documents archive, which contains more than 1100 Dutch government documents obtained through two Freedom of Information Act requests in 2000 and 2011. ${ }^{13}$ We searched the entire archive using a snowball strategy. We initially used broad Dutch search terms such as 'Artikel 5.3' (Article 5.3), and then more specific terms identified from retrieved documents. The documents were provided with additional context by consulting secondary data sources (eg, government documents and news articles) and a review of verbatim records of plenary sessions of COP3 and Article 5.3 committee reports. All textual data were organised chronologically and inductively coded applying the techniques of thematic analysis. ${ }^{14}$

\section{RESULTS}

\section{Minister Hoogervorst: first reference to Article 5.3}

On the day the WHO FCTC opened for signature (16 June 2003), the Dutch employer organisation VNO-NCW (Confederation of Netherlands Industry and Employers) sent a letter on behalf of the Dutch tobacco manufacturers to Hans Hoogervorst, the newly appointed health minister and member of the liberal-conservative People's Party for Freedom and Democracy (Volkspartij voor Vrijheid en Democratie; VVD). ${ }^{15}{ }^{16}$ VNONCW is the peak-level business organisation in the Netherlands, representing most Dutch medium-sized companies and all large corporations, including tobacco trade associations which serve on its general management board. ${ }^{17} \mathrm{VNO}-\mathrm{NCW}$ requested that the Ministry of Health revive regular ministerial level meetings between the tobacco industry and the health ministry. These had been abandoned in 1996, under the leadership of Health Minister Els Borst, a medical doctor dedicated to a strong tobacco control agenda. She had moved supervision for tobacco control from the Ministry of Economic Affairs (Ministerie van Economische Zaken; EZ) to the Ministry of Health and had suspended ministerial level meetings. ${ }^{10} 18$ Thereafter, VNO-NCW had repeatedly requested that regular ministerial level meetings be reinstalled to discuss tobacco control policy but had been unsuccessful, ${ }^{15}$ which effectively limited meetings to matters of implementation with civil servants. ${ }^{19}{ }^{20}$ Civil servants' refusal to accede to industry requests had moved the industry to lobby for regular ministerial level meetings instead. ${ }^{19}$ In the 16 June letter, VNONCW sought to formalise these ad hoc requests by proposing meetings at 'three levels': (1) expert meetings to discuss general aspects of tobacco policy where both tobacco industry and societal and health organisations would be represented; (2) continuation of meetings between industry representatives and civil servants from the health ministry to discuss matters of implementation of tobacco policy; and (3) ministerial level meetings between ministers of health and economic affairs and industry chief executive officers. ${ }^{16}$

The health ministry were open to exploring the first type of meeting and issued a survey to industry and civil society actors to assess interest. ${ }^{21}$ On 2 November 2003, a senior civil servant at the ministry informed Minister Hoogervorst that the consultation had found insufficient support for such meetings. ${ }^{22} \mathrm{He}$ advised that contact be limited to the ongoing 'administrative level' meetings focusing on 'concrete policy matters' and that ministerial level talks be restricted to instances where 'there [was] a substantial need'. ${ }^{22}$ Hoogervorst took the advice and informed the industry that 'no regular tobacco control policy meetings will take place'. ${ }^{23}$

Stichting Sigaretten Industrie (SSI): Dutch Cigarette Manufacturers Association reopened the issue in December 2004, sharing its wish with a new senior civil servant to have 'tentative meetings on a quarterly basis' with the minister. ${ }^{24}$ The request was discussed with Minister Hoogervorst, who was not receptive to the idea. However, in his reply to the SSI, the civil servant noted that 'it speaks for itself that lower level meetings between the ministry and the industry can take place when there are issues that concern the industry directly, such as modification of cigarette packaging, ${ }^{25}$

In a January 2006 letter to Hoogervorst, SSI and Vereniging Nederlandse Kerftabakindustrie (VNK): Dutch Fine Cut Tobacco Industry Association offered to make a 'constructive contribution' to tobacco control policy, proposing dialogue and cooperation regarding the development of future regulation regarding tobacco products and tobacco use. ${ }^{26}$ Hoogervorst declined, restating his opposition to regular meetings and collaboration on tobacco control policy, noting the outcome of the earlier consultation by way of support. ${ }^{27}$ In addition, he referred to the FCTC for the first time, which had been ratified by the Dutch government the year before, noting that 'the FCTC offers no starting point for the kind of collaboration between tobacco industry and government you are proposing' and that while it did 'not rule out consultation and contact between the government and the tobacco industry', it limited interactions to 'issues of implementation', such as 'transitional periods regarding new legislation'. ${ }^{27}$

\section{Minister Ab Klink: disregard of Article 5.3}

In February 2007, a new government came to power, led by the Christian-Democrats (Christian Democratic Appeal (CDA) party), with $\mathrm{Ab}$ Klink (CDA) replacing Hoogervorst as health minister. The documents covering Klink's tenure indicate a subtle, but distinctive change in the Ministry of Health's approach to interacting with the industry. Already by March 2007, civil servants from the ministry met with VNK and $\mathrm{SSI}^{28}$ following a request from VNO-NCW to Minister Klink to discuss tobacco control policy. ${ }^{29}$ Civil servants, concerned by the minister's willingness to hold direct talks with the industry, produced a letter, signed by the Minister, which ruled out collaboration on tobacco control policy and confirmed the standing policy against regular talks (but allowing ad hoc talks necessary for policy implementation). ${ }^{28}$ Despite this, Klink met with representatives from SSI, VNK, VNO-NCW and the Dutch Cigar Industry Association (Nederlandse Vereniging voor de Sigarenindustrie; NVS) on 10 July. ${ }^{30}$ In a letter to Klink, industry representatives described the meeting as 'exceptionally constructive' and expressed their wish to continue similar meetings in the future. ${ }^{30}$ The letter noted that the minister had expressed an interest in receiving information from the industry on less harmful tobacco products and on smuggling and counterfeit cigarettes. On the topic of illicit trade it was agreed that the industry could give a presentation at the ministry. SSI and VNK further noted that the Ministry of Finance had expressed a desire to 'structure and intensify the existing contacts with the tobacco industry on smuggling and counterfeiting. ${ }^{30}$ The minister's decision to open up to the industry appears to have sat uneasily with civil servants at the health ministry: the Director-General (DG) prepared a letter for the minister to sign (which he did), in which Klink declined to have a follow-up meeting (stressing that there were currently no 
'matters of implementation' to discuss) and proposed that the SSI direct future questions to the DG. ${ }^{31}$

In addition to seeking direct access to Dutch policymakers, industry actors also sought to take advantage of the Netherlands' role in shaping the Article 5.3 Guidelines. The Guidelines represented one of the key achievements of the COP3 in Durban (November 2008). Work on the Guidelines had been led by a Key Facilitators Working Group, chaired by a Dutch civil servant, which had begun work on a draft text in December 2007. A first draft had been produced in March 2008 and subsequent iterations were discussed at a series of meetings in June. These meetings coincided with correspondence (23 June 2008) from SSI to the Ministry of Health. ${ }^{32}$ The industry expressed concerns that Article 5.3 Guidelines would have the effect of excluding industry interests from national decision-making processes about tobacco regulation. They requested that the ministry 'reject' any such suggestion during COP3. SSI further argued that the industry's exclusion 'would be in conflict with both internationally accepted practice-of which stakeholder consultation [was] an essential part-and [with] national constitutional principles and provisions'. The letter referred to European principles of 'good governance', which were described as a means of ensuring the 'independence and impartiality of decision making, as acknowledged by the United Nations and the Organisation for Economic Co-operation and Development $(\mathrm{OECD})$ in the European "Better Regulation" programme'. ${ }^{32}$ They further argued that such stakeholder involvement would increase the legitimacy, effectiveness and quality of law making and resonated with the thinking of the Dutch Council of State, the highest advisory body to the government, which had recently described the importance of taking account of the interests of all stakeholders as a principle of good law making.

The Ministry of Health's written response (5 September) ${ }^{33}$ made it clear that Article 5.3 Guidelines 'emphasise that the interests of the tobacco industry are fundamentally opposed to public health interests of governments and that for this reason caution and transparency are required'. However, it also contained words of reassurance: 'First of all, I want to stress that it concerns non-binding guidelines. (...) Secondly, it is certainly not a matter of excluding the industry.' The letter concluded with an invitation for SSI and VNK to inform the Ministry in writing about their thoughts on the Guidelines, when the final documents for COP3 had been made public.

While this exchange of letters was taking place, VNK contacted civil servants from other ministries to voice their concerns. ${ }^{34}$ In a letter dated 16 July 2008, VNK informed officials at both the Ministries of Finance and Economic Affairs about the industry's wish to have a say in the Dutch government's position regarding Article 5.3 Guidelines and Dutch input into a European position at COP $3{ }^{34} \mathrm{VNK}$ argued that issues considered by the Ministry of Health were of interest to other ministries and gave examples of a point of sale display ban and restriction of tobacco selling points. VNK stressed that the proposal regarding Article 5.3 Guidelines would 'severely restrict' industry involvement since future contact would be limited to 'implementation of legislation and only upon invitation of the regulator itself ${ }^{34}$ They added that meetings beyond this were necessary to prevent the regulatory process from becoming 'needlessly costly or distorting the market'; concluding, 'it is of the utmost importance that our current engagement with policy makers will not be restricted'. ${ }^{34}$ Industry pressure continued until COP3 in November 2008. At one point, VNK requested to meet Klink personally to discuss the Guidelines. ${ }^{35}$ It expressed concern that the government's emerging position on the Guidelines was 'not consistent' with views 'previously occupied and publicly communicated by you' and that use of the word 'should' rather than 'may' in the draft text in the context of partnerships and voluntary agreements ('Parties should establish policies that probibit partnerships or non-enforceable or nonbinding agreements and partnerships as well as any voluntary arrangement with the tobacco industry') implied 'a much smaller amount of permissiveness' than previously suggested, referring to the letter from the ministry from 5 September. ${ }^{35}$ VNK further inquired whether the government would register its reservations at COP3 in Durban about the Guidelines. They pointed to the fact that it would be 'very unlikely' that the Netherlands would 'hold other positions at a later stage at the national level', once the current viewpoints in the draft Guidelines had been endorsed, especially since the Netherlands had been a key facilitator in drafting them. By way of forcing the ministry's hand, they stated their intention to request members of parliament to raise questions about the matter to the minister if the industry were not informed about the government's position. ${ }^{35}$ In a separate letter to the ministry, Philip Morris International (PMI) also stated that the Guidelines 'overlook the fact that in complex areas of regulation, the expertise of the tobacco companies is especially important to develop regulations that are technically viable, practically workable and enforceable'. ${ }^{36}$

The industry and ministry appeared to have found common ground on the interpretation of Article 5.3 during a meeting on 11 December $2008 .{ }^{37}$ A summary of main points of the meeting, sent by SSI and VNK to Klink, referred to the fact that Klink had mentioned the principle of subsidiarity (the principle that decision-making should take place at the lowest possible administrative level), a central element in CDA ideology, ${ }^{10}$ to the effect that the Netherlands 'should not have to implement FCTC guidelines if it already has a good prevention policy in place'. In addition to informing him that they were 'very grateful' for echoing their position, SSI and VNK welcomed Klink's promise that continued meetings could take place in the case of 'specific concerns or (policy) developments'. ${ }^{37}$

Further discussion on 'circumstances and conditions under which future consultation might take place' was held in a meeting between the DG (Paul Huijts) and VNK on 24 August 2009..$^{38}$ According to Huijts, consultation with the industry needed to contribute to 'a two-way exchange of information' and build mutual trust. ${ }^{38}$ Huijts also indicated support for 'periodic meetings with the industry, together with other relevant ministries', provided there were relevant issues to discuss, and VNK indicated its satisfaction with this arrangement. ${ }^{38}$

On 15 January 2010, Huijts met with industry representatives (SSI, VNK, NVS) and VNO-NCW to discuss the implications for the industry of upcoming FCTC guidelines on tobacco ingredients (Articles 9 and 10). ${ }^{39}$ The matter of 'improving communication [between industry and government] and having regular meetings' was also discussed. ${ }^{40}$ The meeting resulted in a snap public consultation on tobacco ingredients with tight timelines, in respect of which submissions from STIVORO (Stichting Volksgezondheid en Roken [Dutch Smoking or Health Foundation]; the national expert centre for tobacco control) and the Rijksinstituut voor Volksgezondheid en Milieu (the National Institute for Public Health and the Environment) were also invited. ${ }^{41}$ In addition, the ministry agreed to organise a national consultation (invitation only) later the same year where the industry would have the opportunity to comment on various policy proposals, including the revision of the European Tobacco Products Directive (EUTPD), specifications relating to Articles 9, 10 and 15 of the FCTC and the development of a new national Programme for 
Tobacco Control for 2011-2015. ${ }^{1042}$ The industry's summary of the meeting (shared with the DG and signed by VNK, SSI, PMI and NVS) ${ }^{42}$ reported that the DG had agreed to be 'open for interim contacts, interventions, signals of questions [by the industry] if there is a reason for it' and, importantly, to inform the industry about the government's thinking on new policies before they were communicated publicly. A separate letter from PMI noted that this represented 'a good basis for a constructive exchange of ideas between the health ministry and the tobacco industry'. ${ }^{43}$ This new accord was reflected in a request (March) by civil servants at the health ministry to visit Philip Morris' production facility in the city of Bergen of Zoom ${ }^{44}$ and a meeting (11 June) between Huijts and the industry to discuss international developments regarding tobacco ingredients. ${ }^{45}$

Not long after 'normalising' access to the Ministry of Health, industry representatives met with civil servants at the Ministry of Economic Affairs (EZ) (5 October) to explore the potential role of this ministry in shaping the Dutch government's approach to emerging tobacco control topics. The range of policies under discussion was extensive and included FCTC Articles 9 and 10 on tobacco ingredients, the process of reviewing the EUTPD, proposed display bans, pictorial health warnings on cigarette packs and a new national tobacco control plan. ${ }^{46}$ Shortly afterwards, industry actors wrote to officials from EZ, reporting both their satisfaction with the meeting and their support for a recent request by VNO-NCW that EZ has a stronger say in national and international tobacco control policymaking. ${ }^{46}$ The letter noted that both the industry and the VNO-NCW would very much see that the trade ministry 'would again become co-signer of the Tobacco Law'.

\section{Minister Schippers: tobacco control advocacy organisations demand stricter interpretation of Article $\mathbf{5 . 3}$}

In October 2010, Edith Schippers (VVD) replaced Klink as health minister. In a letter to Schippers shortly after her appointment, SSI and VNK referred to 'pleasant and constructive contacts' when she was a member of parliament and registered their hope of being able to talk with her in person. ${ }^{47}$ In her reply (10 December), Schippers wrote: 'I appreciate the intention to invest further in the coming time in an open and constructive exchange of ideas on various international topics. ${ }^{48}$ In the meantime, $\mathrm{VNO}-\mathrm{NCW}$ wrote to $\mathrm{EZ}$ requesting that officials discuss the idea of restoring the ministry's influence on tobacco control 'to its former glory' with the new minister of EZ, Maxime Verhagen. ${ }^{49}$ An internal memo written in response to the email indicates that civil servants advised the Minister not to take up the suggestion on the basis that industry interests were already taken sufficiently into account by the Ministry of Health when considering new tobacco control policy. ${ }^{50}$

During this period, Dutch public health advocates were coming to recognise the importance of Article 5.3, ${ }^{51}$ and had begun to exclude the industry from conferences and meetings. On 3 February 2011, the industry sent a letter to the ministry complaining about advocacy organisations' use of Article 5.3 and sought reassurance that industry-government exchanges would remain unaffected. ${ }^{52}$ The ministry's reply stressed that when the Netherlands had approved Article 5.3 it had stated that 'the sale of tobacco is a legal economic activity and that contacts with the tobacco industry as a stakeholder must therefore in general remain possible'. ${ }^{53}$

On 21 October 2011, Schippers' former ties with the tobacco industry (which earned her the nickname 'Minister of Tobacco') were the subject of a Dutch investigative current affairs programme. ${ }^{54}$ This marked the beginning of a period in which the government's relationship with the industry attracted much attention in parliament and the media. Over the next 2 years, Schippers repeatedly had to answer questions in parliament about her ties with the industry and permissive interpretation of Article 5.3..$^{55}$ Schippers dismissed the idea of establishing a protocol governing how civil servants should deal with the industry. She argued that civil servants should be able to speak to both proponents and opponents of tobacco ${ }^{55}$ and that she placed her trust in their integrity to decide how best to deal with information from the industry. ${ }^{55}$

\section{State Secretary Martin van Rijn: codifying of Article 5.3}

The political salience of tobacco industry interference continued after November 2012, when a new government took office and State Secretary Martin van Rijn (Labour Party) took over the tobacco portfolio from Schippers. In 2014, the Youth Smoking Prevention Foundation commenced a legal action against the Dutch government, accusing the state of having illegal contacts with the industry. Based on Freedom of Information Act documents, the Foundation argued that the Dutch government had systematically violated Article 5.3 by maintaining frequent contact with the industry between 2009 and 2014. ${ }^{57}$ Around the same time, a report on Article 5.3's implementation was published, commissioned by the Dutch Alliance for a SmokeFree Society. ${ }^{58}$ The report concluded that there was 'no visible development or enforcement' of Article 5.3 in the Netherlands, and that the government did not give it sufficient priority.

The legal case proved unsuccessful. The Dutch court concluded that the Guidelines did not form part of the FCTC and, as such, were not considered legally binding. ${ }^{59}$ However, the case did result in a more strict approach to interpreting Article 5.3 by the government. ${ }^{59}{ }^{60}$ In September 2015, a year after the case, the Ministry of Health distributed a document to parliament clarifying the government's interpretation of Article 5.3. ${ }^{61}$ The document noted that contact with the industry was to 'be restricted to matters of technical execution'. The following year, a code of practice was sent to all ministries, provinces and municipalities with an accompanying letter underlining the importance of Article 5.3. ${ }^{62}$ The code declared that regular meetings would no longer be allowed and that contact with the industry should be restricted to 'issues of technical implementation' and public consultations. ${ }^{62}$ Cooperation from all levels of government with industry corporate social responsibility activities was also prohibited. In addition, the code sought to ensure that interactions were transparent: records of exchanges (emails, letters, notes of meetings) are now published on a government website. $^{63}$

\section{DISCUSSION}

Our findings illustrate several important points relevant to understanding contemporary industry political activity and implementation of Article 5.3. First, effective implementation, particularly in the absence of formal codes of practice, appears closely tied to ministerial interpretation. The government's initial decision not to codify Article 5.3 appears to have created an indeterminate administrative environment in which ministers' interpretation of Article 5.3 could shift according to their political caprice, despite what appears to be relatively consistent advice from civil servants to keep to a strict interpretation. In contrast to previous health minsters, Klink (2007-2010) and Schippers (2010-2012) did not regard contacts with the industry as inherently problematic. In effect, these ministers subscribed to the idea that 
countries had freedom in implementing Article 5.3, partly on the basis that the Guidelines were non-binding and citing the subsidiary principle (that the resolution of social and political issues should be addressed at the most local level consistent with their resolution) as justification. Under consistent pressure from the industry, an initial strict view of Article 5.3 (contact limited to technical matters relating to the implementation of new policy) increasingly gave way to increased contact with the industry on all aspects of tobacco control. During these years, the tobacco industry was able to have multiple meetings with both highranking civil servants and ministers.

Our study does not provide an exhaustive account of all lobbying regarding the interpretation of the Guidelines because it is limited to letters and emails made public in response to freedom of information requests. In addition, many of the statements outlined above represent industry perceptions and may not be a true reflection of events. For example, industry letters commend Minister Klink for having made reservations during the COP3 regarding the Guidelines even though such reservations are not formally reported in the verbatim records of the COP3 sessions in Durham. ${ }^{64}$

Our data further demonstrate the deep concerns of industry actors about the prospect of being frozen out of tobacco control policymaking. This was exemplified by both the lengths to which industry actors went in securing terms of engagement with health officials and by the persistent lobbying on the draft of Article 5.3 Guidelines. In addition to pushing for a cooperative approach to policy development, characterised by persistent efforts to secure high-level access to health officials, the data also highlight the considerable efforts (although unsuccessful) the industry made in shifting the governance of tobacco policy away from the Ministry of Health back to the Ministry of Economic Affairs. This highlights a widely recognised, but still underexplored, aspect of the industry's political strategy, which centres on diluting the priority given to health in the governance of tobacco, and is consistent with PMI's efforts to increase the number of delegates at COP meetings who are not from health ministries or involved in public health. ${ }^{65}$

Our findings also highlight the potential vulnerability of meetings of the COP to industry lobbying at the national level. This remains an under-researched area. ${ }^{66}$

Finally, our data highlight the interdependence of industry lobbying, public health advocacy and formal codification of the Guidelines in shaping effective implementation of the Guidelines. The recent decision in the Netherlands to produce a formal code of practice on industry-government interactions was the direct result of public health advocacy aimed at ensuring that key aspects of Article 5.3 are strictly observed. This included naming and shaming of government contacts with the industry, parliamentary questions about industry-government contacts, a report outlining how Article 5.3 should be observed in practice and, most importantly, a court case against the State. Our data do not allow firm conclusions to be drawn about the independent effect of the code of practice on industry-government interactions. Nonetheless, its introduction has coincided with radically reduced industry access to public and elected officials ${ }^{6768}$ and its existence is likely to limit ministerial discretion over how Article 5.3 is interpreted. In this respect, our findings are consistent with those of Hawkins and Holden who note the close relationship between uncodified working norms and weak implementation of Article 5.3. ${ }^{6}$ The events leading up to the Dutch National Prevention Accord (2019-2021) ${ }^{69}$ illustrate this changed approach. The Accord was the result of an extensive process of consultation and negotiation between government, civil society and the business community on the selection of new policy measures aimed at reducing alcohol, diet and tobacco-related diseases. ${ }^{70}$ In contrast to food and alcohol industries, representatives from tobacco and e-cigarette (and the VNO-NCW because of its past actions in lobbying on behalf of the tobacco industry) were not invited to participate, a direct consequence of the strict implementation of Article 5.3.

\section{What this paper adds}

- Previous research has highlighted the risks of non-codified general commitments to Article 5.3 Framework Convention on Tobacco Control. This study provides direct evidence of these risks and points to the value of codified commitments to moderating ministerial discretion over the interpretation of Article 5.3.

- The study illustrates the value of intensive health advocacy to ensuring strong implementation of Article 5.3 and outlines specific actions that public health advocates can undertake to strengthen implementation of Article 5.3.

- The study highlights the vulnerability of meetings of the Conference of the Parties to industry lobbying at the national level.

Twitter Marc C Willemsen @Marc_Willemsen

Acknowledgements We thank Jessamina Lie for doing a search of the Truth Tobacco Industry Documents and translating Dutch texts into English, and Katherine Smith for her advice on an early version of the paper.

Contributors MCW conceived the paper and wrote the first draft. MCW and GF contributed with revisions and approved the final version of the paper.

Funding The authors have not declared a specific grant for this research from any funding agency in the public, commercial or not-for-profit sectors.

Competing interests None declared.

Patient consent for publication Not required.

Provenance and peer review Not commissioned; externally peer reviewed.

Data availability statement Data may be obtained from a third party and are not publicly available.

\section{ORCID iD}

Marc C Willemsen http://orcid.org/0000-0001-9387-592X

\section{REFERENCES}

1 WHO. WHO framework convention on tobacco control. Geneva: World Health Organization, 2003

2 WHO. Guidelines for implementation of article 5.3 of the who framework convention on tobacco control. Geneve: WHO, 2008.

3 Maloney WA, Jordan G, McLaughlin AM. Interest groups and public policy: the Insider/ Outsider model revisited. J Public Policy 1994;14:17-38.

4 Malone RE, Bialous SA. WHO FCTC article 5.3: promise but little progress. Tob Control 2014;23:279-80

5 Fooks GJ, Smith J, Lee K, et al. Controlling corporate influence in health policy making? An assessment of the implementation of article 5.3 of the World Health Organization framework convention on tobacco control. Global Health 2017;13:12.

6 Hawkins B, Holden C. European Union implementation of article 5.3 of the framework convention on tobacco control. Global Health 2018;14:79.

7 Assunta M, Dorotheo EU. SEATCA tobacco industry interference index: a tool for measuring implementation of WHO framework convention on tobacco control article 5.3. Tob Control 2016:25:313-8.

8 Siaroff A. Corporatism in 24 industrial democracies: meaning and measurement. Eur J Polit Res 1999;36:175-205.

9 Kickert WJM. Beneath consensual corporatism: traditions of governance in the Netherlands. Public Adm 2003:81:119-40.

10 Willemsen MC. Tobacco control policy in the Netherlands: between economy, public health, and ideology. New York: Palgrave Macmillan, 2018.

11 WHO. Reporting instrument of the WHO framework convention on tobacco control: the Netherlands. Geneva: WHO, 2018.

12 WHO. Elaboration of guidelines for implementation of Article 5.3 of the Convention Conference of the Parties to the WHO Framework Convention on Tobacco Control 
Third session Durban, South Africa, 17-22 November 2008. Geneva: World Health Organisation, 2008.

13 Legacy Tobacco Documents Library. New Dutch tobacco industry documents 2014.

14 Namey EE, Guest G, MacQueen KM. Applied Thematic Analysis. London: Sage, 2012.

15 VNO-NCW. Letter 22 April 2003. Bates No JB0269, 2003. Available: https://www.indu strydocumentslibrary.ucsf.edu/tobacco/docs/jihb0191

16 VNO-NCW. Regulier tabaksoverleg. 16 June 2003. Bates No JB3581, 2003. Available: https://www.industrydocuments.ucsf.edu/docs/yldn0217

17 VNO-NCW. Samenstelling Dagelijks en Algemeen Bestuur Vereniging VNO-NCW. Then Hague: VNO-NCW, 2012

18 Willemsen MC. Understanding tobacco control policy at the national level: bridging the gap between public policy and tobacco control advocacy. Tob Induc Dis 2018;16

19 Ministerie van Volkgezondheid Welzijn en Sport. Regeling lijsten tabaksingrediënten. 7 May 2003. Bates No JB3264, 2003. Available: https://www.industrydocument slibrary.ucsf.edu/tobacco/docs/ftdn0217

20 Ministerie van Volksgezondheid Welzijn en sport. Regulier overleg tabaksontmoedigingsbeleid. 20 May 2003. Bates No JB0270, 2003. Available: https:// www.induJB0270strydocumentslibrary.ucsfedu/tobacco/docs/kjhb0191

21 Ministerie van Volkgezondheid Welzijn en Sport. Overleg. 19 May 2003. Bates No JB0272, 2003. Available: https://www.industrydocumentslibrary.ucsfedu/tobacco/ docs/mihb0191

22 Ministerie van Volksgezondheid Welzijn en Sport. Overleg 5/11/03 Tabaksfabrikanten - VWS. 5 November 2003. Bates No JB3269, 2003. Available: https://www.industry documentslibrary.ucsf.edu/tobacco/docs/fnfn0217

23 Hoogervorst H. Overleg. 4 December 2003. Bates No JB0278, 2003. Available: https:// www.industrydocumentslibrary.ucsf.edu/tobacco/docs/sihb0191

24 SSI. Knelpunten Tabakswet. 20 December 2004. Bates No JB3521, 2004. Available: https://www.industrydocumentslibrary.ucsf.edu/tobacco/docs/krwn0217

25 Dortland R. Tabakswet. 2 March 2005. Bates no JB3525, 2005. Available: https:// www.industrydocumentslibrary.ucsf.edu/tobacco/docs/fswn0217

26 VNK. Plan van aanpak SSI-VNK. 25 January 2006. Bates No JB0411, 2006. Available: https://www.industrydocumentslibrary.ucsf.edu/tobacco/docs/fshb0191

27 Hoogervorst H. Plan van aanpak SSI-VNK. 9 March 2006. Bates No JB3333, 2006. Available: https://www.industrydocumentslibrary.ucsf.edu/tobacco/docs/ftwn0217

28 De Goeij JIM. Gesprek op 9 maart jl. 29 March 2006. Bates No JB3525, 2006. Available: https://www.industrydocumentslibrary.ucsf.edu/tobacco/docs/jtwn0217

29 Wientjes BEM, Hermans L. Beleid inzake alcohol en tabak [letter] 2007.

30 SSI, VNK. Overleg met VNO-NCW en de tabaksindustrie (SSI, VNK en NVS). 9 August 2007. Bates No JB0454, 2007. Available: https://www.industrydocumentslibrary.ucsf. edu/tobacco/docs/qzhb0191

31 Klink A. Tabaksontmoedigingsbeleid (letter to SSI). 20 November 2007 Bates No JB0454, 2007. Available: https://www.industrydocumentslibrary.ucsf.edu/tobacco/ docs/qzhb0191

32 Roelofs WJ. Artikel 5.3 van het Kaderverdrag inzake tabaksontmoediging: goede gelegenheid ter verbetering van de transparantie en de integriteit van het wetgevingsproces. 23 June 2008. Bates No JB0562, 2008. Available: https:// industrydocuments.library.ucsf.edu/tobacco/docs/qgfn0217

33 Ministerie van Volksgezondheid Welzijn en Sport. WHO FCTC. 5 September 2008. Bates No JB2823, 2008. Available: https://industrydocuments.library.ucsf.edu/tobacco/ docs/rgfn0217

34 VNK. Achtergrondnotitie over doorwerking tabaksverdrag in NL en input vanuit NL. 16 July 2008. Bates No JB0052, 2008. Available: https://industrydocuments.library. ucsf.edu/tobacco/docs/rlgb0191

35 VNK. Standpuntinname Nederland inzake WHO Guidelines. 7 October 2008. Bates No JB2831, 2008. Available: https://industrydocuments.library.ucsf.edu/tobacco/docs/ kkcn0217

36 Morris P. Verzoek tot afspraak met Philip Morris Holland B.V. 17 October 2008. Bates No JB0417, 2008. Available: https://industrydocuments.library.ucsf.edu/tobacco/docs/ Ishb0191

37 SSI, VNK. Gesprek 11 december jl. inz. WHO FCTC - draft guidelines. 5 January 2009. Bates No JB0413, 2009. Available: https://industrydocuments.library.ucsf.edu/tobacco/ docs/hshb0191

38 Ministerie van Volksgezondheid Welzijn en Sport. Bedankbrief gesprek VNK. 29 October 2009. Bates No JB0611, 2009. Available: https://www.industrydocument slibrary.ucsf.edu/tobacco/docs/mzhb0191

39 Morris P. RE: Afspraak over ingrediënten van tabaksproducten. 11 December 2009. Bates No JB0618, 2009. Available: https://www.industrydocumentslibrary.ucsf.edu/ tobacco/docs/ynxb0191

40 Van Bolhuis AMP. Gesprek tabaksindustrie 15 januari. 13 January 2010. Bates No JB2839, 2010. Available: https://www.industrydocumentslibrary.ucsf.edu/tobacco/ docs/nzcn0217

41 Ministerie van Volkgezondheid Welzijn en Sport. Consultatie. 20 January 2010. Bates No JB0628, 2010. Available: https://www.industrydocumentslibrary.ucsf.edu/tobacco/ docs/xyxb019
42 NVK, NVS, SSI. Gesprek 15 januari jl. inzake beleidsontwikkelingen. 27 januari 2010 Bates No JB0562, 2010. Available: https://www.industrydocumentslibrary.ucsf.edu/ tobacco/docs/\#id=hkxb0191

43 Morris P. RE: consulatie. 20 January 2010. Bates No JB0629, 2010. Available: https:// www.industrydocumentslibrary.ucsf.edu/tobacco/docs/jyxb0191

44 Benelux PM. Mogelijkheid tot werkbezoek Phillip Morris Holland. 29 January 2010. Bates No JB0420, 2010. Available: https://www.industrydocumentslibrary.ucsf.edu/ tobacco/docs/yshb0191

45 Van Bolhuis AMP. Gesprek tabaksindustrie 11 juni. 8 June 2010. Bates No JB0127, 2010. Available: https://www.industrydocumentslibrary.ucsf.edu/tobacco/docs/ mqgb0191

46 VNK, NVS. Gesprek 5 oktober jl. inzake ontwikkelingen tabaksbeleid. 20 October 2010. Bates No JB0533, 2010. Available: https://industrydocuments.library.ucsf.edu/ tobacco/docs/|xxb0191

47 SSI, VNK. Beleidsvoornemens tabaksontmoediging. 25 October 2010. Bates No 3913, 2010. Available: https://www.industrydocuments.ucsf.edu/docs/jicn0217

48 Schippers EJ. Beleidsvoornemens tabaksontmoediging. 10 December 2010. Bates No JB0562, 2010. Available: https://www.industrydocumentslibrary.ucsf.edu/tobacco/ docs/hkxb0191 [Accessed 2010-12-10].

49 VNO-NCW. alcohol en tabak [email from VNO-NCW to EZ]. 3 Februari 2011. Bates No JB0539, 2011. Available: https://www.industrydocumentslibrary.ucsf.edu/tobacco/ docs/rxxb0191

50 Ministerie van Economische Zaken. Medeondetekening DHW en Tabakswet [nota] Bates No JB0539, 2011. Available: https://www.industrydocumentslibrary.ucsf.edu/ tobacco/docs/rxxb0191

51 Willemsen MC. Roken in Nederland: De keerzijde van tolerantie [inaugural lecture]. Maastricht: Maastricht University, 2011.

52 SSI, VNK. Uitvoering artikel 5.3 FCTC. 3 February 2011. Bates No JB0100, 2011. Available: https://industrydocuments.library.ucsf.edu/tobacco/docs/rygb0191

53 Sonnema M. Uitvoering artikel 5.3 FCTC. 22 February 2011. Bates No JB0562, 2011. Available: https://www.industrydocumentslibrary.ucsf.edu/tobacco/docs/ hkxb0191

54 VARA. Minister of Tobacco [TV documentary]. Zembla. Hilversum: VARA, 2011.

55 Tweede Kamer der Staten-Generaal. Proceedings II, 25 oktober 2011, Vragenuur 2011.

56 Schippers El. Antwoorden op Kamervragen over falende rookpreventie en de banden van de minister met de tabaksindustrie 2011.

57 Anon. Dagvaarding Stichting Rookpreventie Jeugd versus Staat der Nederlanden. Amsterdam, 2014.

58 Groep 0G. Onderzoeks- en adviesrapportage m.b.t. de uitvoering van 'Artikel 5.3 van het WHO-Kaderverdrag inzake tabaksontmoediging (FCTC)' in Nederland 2015

59 Karapetian G, Toebes B. The legal Enforceability of articles 8.2 and 5.3 of the WHO framework convention on tobacco control: the case of the Netherlands. Brill Open Law 2018:1-13.

60 Youth Smoking Prevention Foundation. Huge progress made thanks to court case against Dutch State. Amsterdam: Stichting Rookpreventie Jeugd, 2015.

61 Van Rijn MJ. Tabaksbeleid. Parliamentary Papers I, 2015-2016, 32.011-c. The Haque, 2015.

62 Tweede Kamer der Staten-Generaal. Parliamentary papers II. Verduidelijking invulling artikel 5.3 WHO-Kaderverdrag, 2016

63 Ministerie van volkgezondheid Welzijn en Sport. Duidelijkheid over contact met de tabaksindustrie 2018.

64 Convention Secretariat WHO Framework Convention on Tobacco Control. Conference of the parties to the who framework convention on tobacco control. third session. Geneve:WHO, 2008.

65 Kalra A, Bansal P, Wilson D, et al. Inside Philip Morris' campaign to subvert the global anti-smoking treaty (the Philip Morris Files, Part 1), 2017. Available: https://www. reuters.com/investigates/special-report/pmi-who-fctc/

66 Plotnikova E, Hill SE, Wright A, et al. Towards 'a balanced delegation' or enhancing global health governance? Analysis of parties' participation in the Conference of the Parties to WHO Framework Convention on Tobacco Control. Tobacco Control 2018:054710.

67 Scheltema Beduin A, Ter Weele W. Lifting the lid on lobbying: enhancing trust in public decisionmaking in the Netherlands. Amsterdam: Transparency International Nederland, 2015

68 Van der Lugt P. Nieuwe tabaksregels dwingen industrie tot bezinning. Follow the money 2016.

69 Ministerie van Volkgezondheid Welzijn en Sport. Nationaal Preventieakkoord: Naar een gezonder Nederland. Den Haag: Ministry of Public Health, Welfare and Sport, 2018.

70 Van Mourik D-JA, Willemsen MC. Netherlands: national prevention ACCORD to improve health and reduce smoking. Tobacco Control 2018. 